\title{
Klasifikasi Batuan Beku Gabbro Pada Citra Sayatan Tipis Menggunakan Multilevel Otsu's Thresholding
}

\author{
Muhammad Dzulfikar Fauzi ${ }^{1}$ \\ ${ }^{1}$ Teknik Informatika, Universitas Islam Negeri Sunan Kalijaga, \\ dzulfikar1234567@gmail.com
}

\begin{abstract}
Abstrak
Citra sayatan tipis batuan merupakan metode pengaman yang digunakan untuk menentukan jenis batuan dan nama dari batuan berdasar pada mineral penyusun. Melakukan pengamatan sayatan tipis sulit dilakukan jika hanya menggunakan bantuan mikroskop polarisasi karena kemampuan mata manusia tidak dapat melakukan identifikasi secara mendetail. Oleh karena itu analisis dan identifikasi mineral menjadi lebih mudah dilakukan dengan bantuan pengolahan citra digital dengan menggunakan algoritma Multilevel Otsu's Thresholding untuk mengetahui kelimpahan mineral batuan beku.

Data yang digunakan dalam penelitian ini menggunakan citra sayatan tipis batuan beku yang diakuisisi dari penggunaan mikroskop polarisasi dengan perbesaran 10x. preprocessing yang dilakukan dengan 2 perlakuan yang berbeda yaitu garyscale dan grayscale dengan k-means untuk mengetahui hasil yang maksimal. Selanjutnya tahap pengolahan dilakukan segmentasi Multilevel Otsu's Thresholding dengan dua nilai ambang. Selanjutnya analisis pada hasil segmentasi untuk mengetahui kelimpahan mineral.

Hasil perhitungan dan analisis yang telah dilakukan pada preprocessing yang menggunakan grayscale dan grayscale dengan k-means yang kemudian di lakukan segmentasi Multilevel Otsu's Thresholding memiliki akurasi paling tinggi 40\% dan 33,57\%. Dari kedua perlakuan dapat disimpulkan bahwa penggunaan k-means pada preprocessing memiliki pengaruh pada pengolahan citra sayatan tipis batuan beku jenis gabbro dengan nilai akurasi tertinggi dari dua perlakuan yaitu $40 \%$ dengan menggunakan preprocessing k-means dengan nilai $k=7$.
\end{abstract}

Kata kunci: citra sayatan tipis, batuan beku, Multilevel Otsu's Thresholding.

The image of a thin section of rock is a rock or mineral observation methods. The mineral content of rocks can be used to determine rock types and names of these rocks. Thin section making observations difficult if only using polarizing microscopy, the ability of the human eyes can not identify in detail. Therefore, the analysis and identification of minerals to be more easily done with the help of digital image processing algorithms using Multilevel Otsu's Thresholding to determine the abundance of igneous minerals.

The data used in this study using the image of a thin section of igneous rock acquired from use polarizing microscope with a magnification of 10x. Preprocessing is performed with two different treatment is grayscale and grayscale with k-means to determine the maximum results. The next stage of the processing is done Multilevel Otsu's Thresholding segmentation with two threshold values. Further analysis of the results of segmentation to determine the abundance of minerals.

The results of calculations and analysis has been done on the preprocessing using grayscale and grayscale with k-means then done Multilevel Otsu's Thresholding segmentation has the highest accuracy of $40 \%$ and $33.57 \%$. Of the two treatments can be concluded that the use of k-means on the preprocessing have an influence on image processing thin section gabbro igneous rock types with the highest accuracy values of the two treatments at $40 \%$ by using the $k$ means preprocessing with a value of $k=7$.

Keywords: Image thin section, Igneous rock, Multilevel Otsu's Thresholding. 


\section{PENDAHULUAN}

Batuan dan mineral merupakan sumber daya alam yang banyak dibutuhkan dan digunakan untuk kehidupan manusia, dan bahan dasar industri. Batuan mengandung mineral yang merupakan bahan non-organik yang dapat digunakan dalam berbagai bidang di antaranya konstruksi bangunan, kesehatan, kecantikan, pertanian, peternakan dan industri. Melihat mineral akan sulit dilakukan jika dilihat secara langsung, mineral akan mudah jika batu yang mengandung mineral di sayat terlebih dahulu.

Sayatan tipis batuan adalah suatu metode pengamatan batuan atau mineral dengan cara membentuk dan menipiskan batuan hingga memiliki ketebalan $0,35 \mathrm{~mm}$, sehingga dapat dijadikan preparat untuk penelitian menggunakan mikroskop polarisasi. Fungsi utama dari sayatan tipis batuan adalah untuk melakukan analisis dan identifikasi mineral yang ada dalam batuan.

Berbagai penelitian tentang segmentasi menggunakan bermacam-macam metode segmentasi seperti adaptive segmentasi, global segmentasi dan segmantasi yang didasarkan pada threshold. Seperti penelitian yang dilakukan oleh Umam (2014) melakukan penelitian tentang segmentasi citra medis pada panoramik gigi, pada penelitian tersebut di lakukan segmentasi dengan mereduksi warna citra panoramik gigi menjadi 64 macam warna dan menggunakan nilai threshold T-cluster sebesar 20. Hasil penelitian menunjukkan bahwa dengan metode yang digunakan dapat mereduksi warna hingga menjadi 64 macam dan menggunakan nilai threshold T-cluster sebesar 20 dapat dihasilkan citra panoramik gigi tersegmentasi dengan rata-rata nilai $Q$ yang paling kecil, yaitu 4,40 [1].

Penelitian ini menggunakan metode Multilevel Otsu's Thresholding dalam melakukan segmentasi pada sayatan tipis batuan beku yang digunakan untuk menghitung kandungan mineral yang dikandung batuan beku dengan membuat suatu prototype untuk menghitung kelimpahan mineral pada sayatan tipis batuan beku dengan mengunakan pengolahan citra digital. Algoritma Multilevel Otsu's Thresholding yang yang telah diteliti oleh Deng-Yuan, TaWei dan Wu-Chic (2011) yang membandingkan beberapa metode Automatic Thresholding, metode Otsu digunakan secara luas dalam bidang computer visionv, video surveillance dan pengenalan pola yang merupakan teknik pengolahan citra tingkat rendah memisahkan objek dari backgrounds. Metode Multilevel Otsu's Thresholding merupakan metode terbaik untuk mensegmentasi gambar, metode Otsu memiliki kompleksitas komputasi tingkat tinggi ketika dilanjutkan ke permasalahan multilevel thresholding [2].

Berdasarkan penjelasan yang dipaparkan, maka penelitian ini menggunakan algoritma Multilevel Otsu's Thresholding sebagai proses segmentasi pada citra sayatan tipis batuan beku untuk diketahui kelimpahan mineral yang dikandung dan penamaan batuan beku berdasarkan hasil segmentasi. Penelitian ini juga menggunakan metode k-means pada preprocessing agar mempermudah dalam mensegmen citra sayatan tipis.

\section{METODE PENELITIAN}

Metode-metode yang digunakan dalam penelitian ini dapat digambarkan dalam beberapa diagram alur sebagai berikut: 


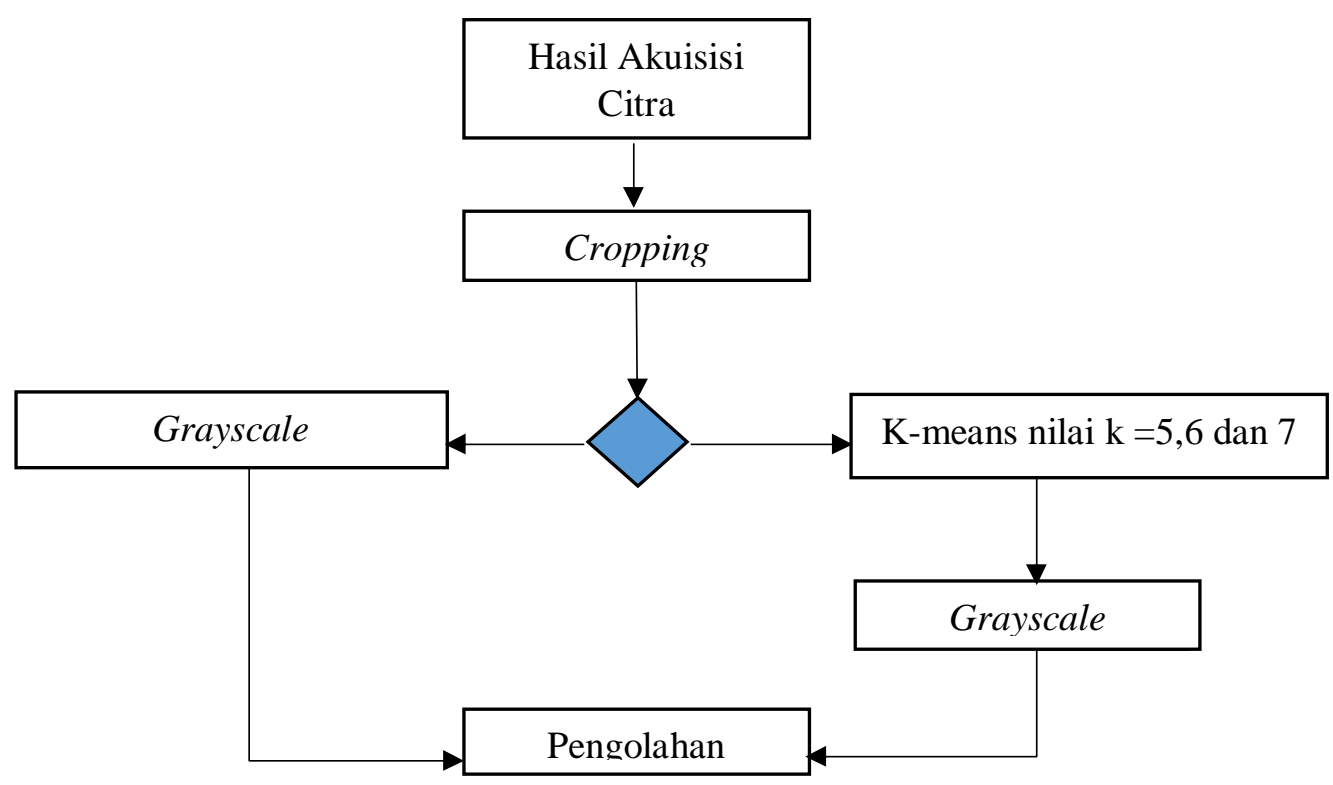

Gambar 1. Alur Preprocessing

Hasil dari cropping citra yang diambil kemudian dilakukan pengolahan dengan dua cara yaitu yang pertama k-means dengan grayscale yang kedua dengan grayscale saja, adapun di proses pengolahan dengan k-means menggunakan nilai $\mathrm{k}=5,6$ dan 7 dengan tujuan untuk mempermudah dalam pengolahan selanjutnya.

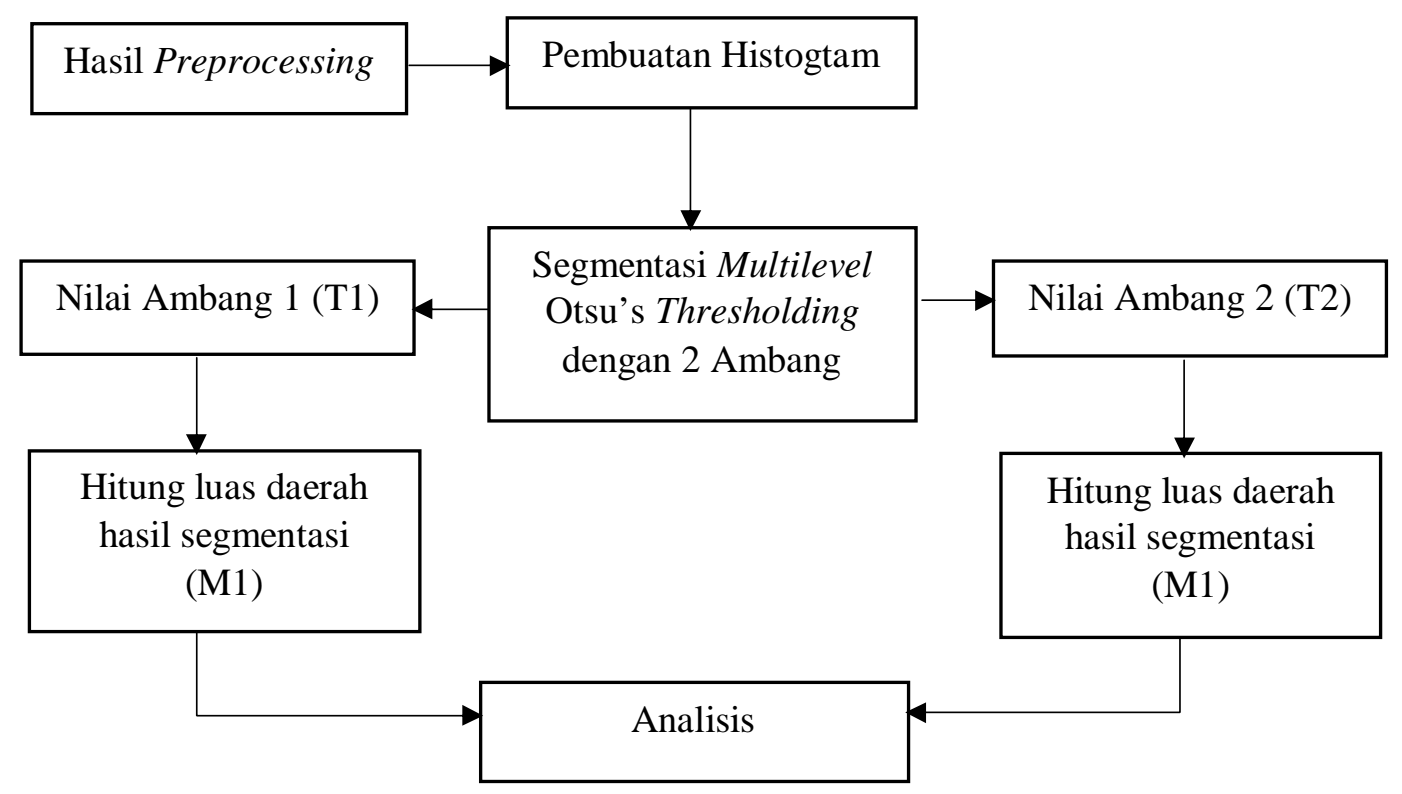

Gambar 2. Alur Pengolahan

Hasil yang telah diperoleh dari proses sebelumnya digunakan untuk mensegmen dengan cara dibuat terlebih dahulu histogram citra yang akan disegmen, segmentasi yang dilakukan menggunakan algoritma multilevel otsu's thresholding dengan 2 ambang threshold yang digunakan untuk mensegmen mineral-mineral yang ada di batuan beku. Setelah didapatkan hasil 
segmentasi kemudian di hitung luasan hasil segmentasi yang merupakan perwakilan dari kelimpahan mineral yang tersegmen.

Tahap selanjutnya yaitu melakukan analisis dengan mengunakan perhitungan Relative Foreground Area Error (RAE) dari hasil segmentasi untuk mengetahui tingkat relative error yang terdapat pada setiap objek pengujian dengan hasil yang diberikan oleh seorang ahli. Tahap selanjutnya dihitung keakuratan dari metode yang digunakan dalam penelitin ini menggunakan confution matrix.

\subsection{Grayscale}

Citra grayscale hanya memiliki informasi tentang intensitas dari cahaya, tidak berupa warna yang terkandung dalam citra. Ada 256 tingkat keabuan dalam citra grayscale dan setiap pixel memiliki intensitas dari 0 hingga 255, dengan 0 menjadi hitam dan 255 menjadi putih. Adapun rumus yang digunakan dalam melakukan grayscale sebagai berikut:

$$
\text { Gray }=\frac{R+G+B}{3}
$$

Dimana Gray merupakan hasil grayscale, $\mathrm{R}$ merupakan nilai dari warna merah yang diambil intensitasnya dari suatu pixel, $\mathrm{G}$ merupakan nilai dari warna hijau yang diambil intensitasnya dari suatu pixel dan B merupakan nilai dari warna biru yang diambil intensitasnya dari suatu pixel, yang kemudian dibagi dengan konstantan 3 yang sudah merupakan ketetapan agar manjadi grayscale suatu citra tersebut [3].

\section{$2.2 K$-means}

Secara umum metode $k$-means memiliki langkah-langkah sebagai berikut [5]:

1. Inisialisasi nilai $k$ cluster dan titik tengah.

2. Untuk setiap pixel, dihitung jarak Euclidean $d$, diantara titik tengah dan setiap titik pixel dapat ditulis dengan persamaan sebagai berikut:

$$
d=\left\|p(x, y)-c_{k}\right\|
$$

3. Menetapkan semua pixel ke pusat terdekat berdasarkan jarak $d$.

4. Setelah semua pixel telah ditetapkan, menghitung ulang posisi baru dari pusat menggunakan persamaan sebagai berikut:

$$
c_{k}=\frac{1}{k} \sum_{y \in c_{k}} \sum_{x \in c_{k}} p(x, y)
$$

5. Ulangi proses sampai memenuh toleransi untuk nilai error.

6. Membentuk ulang pixel hasil cluster hingga menjadi gambar.

\subsection{Metode Segmentasi}

Metode yang digunakan dalam mensegmen citra hasil pengolahan sebelumnya yaitu multilevel otsu's thresholding dengan langkah-langkah sebagai berikut [2]:

$$
p_{i}=\frac{f_{i}}{N}, p_{i} \geq 0, \sum_{i=0}^{L-1} p_{i}=1
$$


Dimana L merupakan tingkat keabuan $(0,1, \ldots, \mathrm{L}-1)$. Jumlah pixel pada $i$ dinotasikan dengan $f_{i}$, dan $N$ merupakan penjumlahan dari semua pixel $N=f_{0}+f_{1}+\cdots+f_{L-1}$.

$$
w_{k}=\sum_{i \in C_{k}} p_{i} \operatorname{dan} \mu_{k}=\sum_{i \in C_{k}} i \cdot p_{i} / w_{k}, k \in\{0,1, \ldots, K-1\}
$$

Dimana $w_{k}$ merupakan kumulatif probabilitas dan $\mu_{k}$ merupakan mean dari tingkat keabuan untuk setiap $C_{k}$ (Cluster).

Intensitas mean dari sebuah citra $\mu_{T}$ dan $\sigma_{B}^{2}$ merupakan varian diantara class yang masing-masing ditetukan sebagai berikut:

$$
\begin{gathered}
\mu_{T}=\sum_{k=0}^{k-1} i \cdot p_{i}=\sum_{k=0}^{k-1} \mu_{k} w_{k} \\
\sigma_{B}^{2}=\sum_{k=0}^{k-1} w_{k}\left(\mu_{\kappa}-\mu_{T}\right)=\sum_{k=0}^{k-1} w_{k} \mu_{k}^{2}-\mu_{T}^{2}
\end{gathered}
$$

Threshold optimal $\left\{t_{0}^{*}, t_{1, \ldots,}^{*} t_{K-2}^{*}\right\}$ dapat ditentukan nilai maksimal antara varian classnya sebagai berikut:

$$
t_{0,}^{*} t_{1, \ldots,}^{*} t_{K-2}^{*}\{\}=0 \quad \underset{0}{\arg }
$$

\subsection{Relative Foreground Area Error (RAE)}

$R A E$ merupakan perbandingan yang didasarkan pada pengukuran daerah hasil segmentasi. Relative Foreground Area Error dapat dirumuskan sebagai berikut:

$$
\begin{aligned}
& \text { RAE }=\frac{A_{0}-A_{T}}{A_{0}}, \text { jika } A_{T}<A_{0} \\
& \text { Atau } \\
& \text { RAE }=\frac{A_{T}-A_{0}}{A_{T}}, \text { jika } A_{T} \geq A_{o}
\end{aligned}
$$

Dimana $A_{o}$ adalah daerah referensi dari citra, sedangkan $A_{T}$ merupakan daerah hasil thresholding citra. Sebaiknya untuk kecocokan daerah hasil yang bagus, nilai $R A E$ adalah 0[6].

\subsection{Confusion Matrix}

Confusion Matrix adalah matriks yang disajikan oleh jumlah benar dan tidak benar yang diprediksi oleh sebuah model yang di bandingkan dengan data aktual. Confusion Matrix terbentuk dari $\mathrm{N}^{*} \mathrm{~N}$ matriks, dimana $\mathrm{N}$ merupakan merupakan jumlah label (classes). Jika kolom merupakan class yang diprediksi, maka baris merupakan class aktual. Dengan menggunakan matriks ini dapat dicari class mana yang rancu dengan class yang lain.

\section{HASIL DAN PEMBAHASAN}

Pengujian citra sayatan tipis batuan beku dengan menggunakan algotrima multilevel Otsu's thresholding ini menggunakan pemrograman C\# dengan menggunakan Visual Studio 2013. Langkah pertama yang dilakukan adalah pengambilan citra sayatan tipis batuan beku 
dengan menggunakan alat batu mikroskop polarisasi dengan perbesaran 10x. Dari hasil pengambilan cirtra sayatan tipis tersebut dilakukan proses cropping yang bertujuan utuk menghilangkan bingkai bulat hitam dari hasil pengambilan gambar dengan mikroskop polarisasi

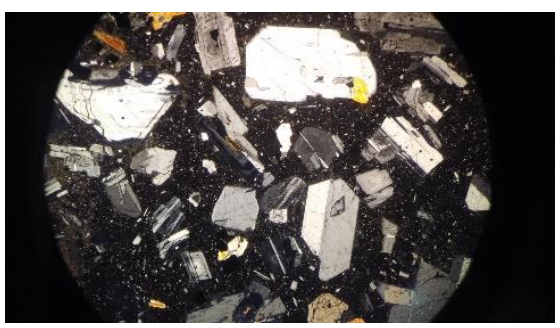

(a). sebelum

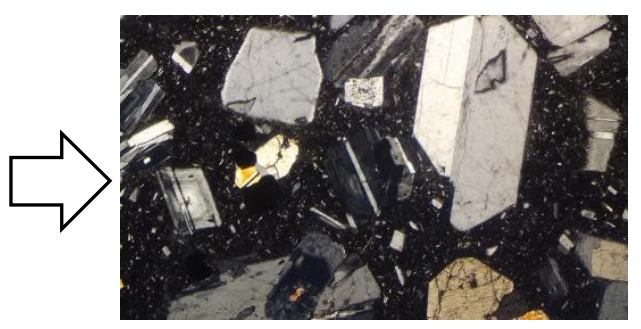

(b).sesudah

Gambar 3. Cropping Citra

Selanjutnya data siap untuk dijadikan inputan pada prototype yang telah dibuat. Langkah pertama yang dilakukan adalah di klastering menggunakan k-means dengan nilai $\mathrm{k}=5,6$ dan 7 yang bertujuan untuk menyamakan intensitas keabuan berdasarkan nilai k yang di inputkan. Tahap awal dari k-means yaitu inisialisasi nilai $\mathrm{k}$ dan titik tengah, dilanjutkan dengan menghitung jarak Euclidean (d) dengan persamaan [2] setelah itu ditetapkan semua pixel ke titik pusat terdekat berdasarkan jarak $d$, setelah semua pixel telah ditetapkan, dilakukan perhitungan ulang posisi baru dari pusat titik menggunakan persamaan [3]. Kemudian ulangi proses sampai memenuhi toleransi nilai error. Tahap terakhir membentuk ulang pixel hasil cluster hingga menjadi gambar seperti gambar awal sebelum pengolahan $k$-means tetapi berbeda pada intensitas keabuan citra yang di hasilkan.

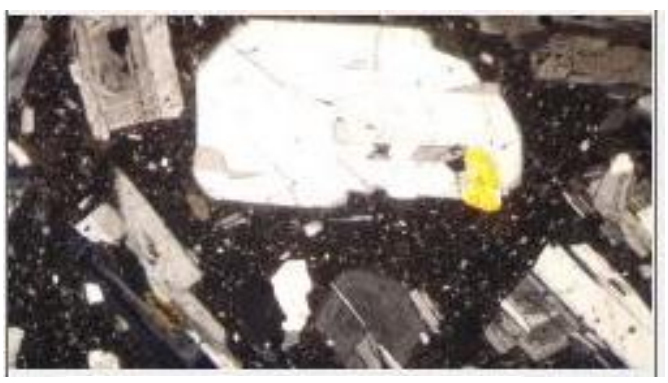

(a) Citra awal

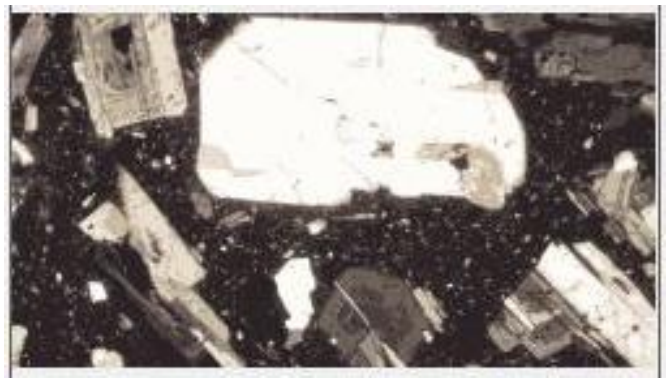

(c) $K$-means k=6

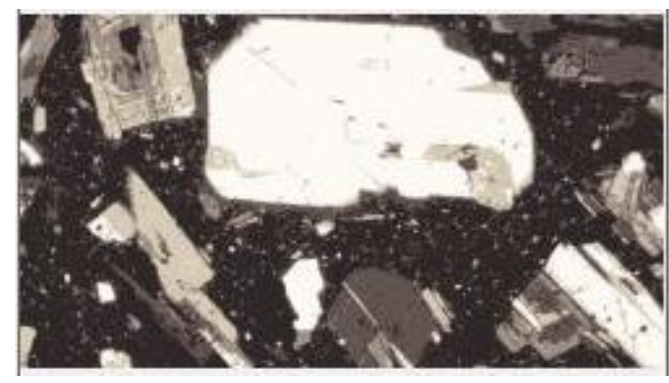

(b) K-means $\mathrm{k}=5$

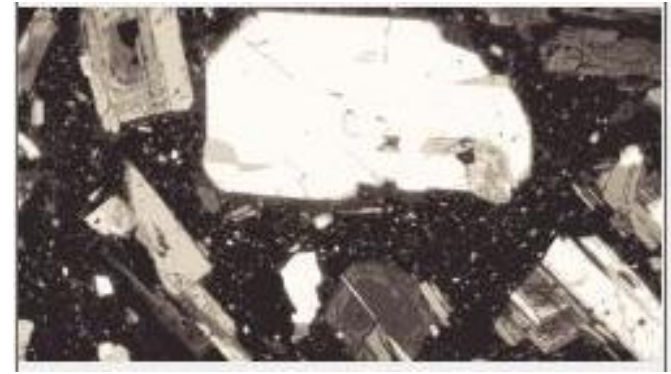

(d) $K$-mens k=7

Gambar 4. Hasil Pengolahan $K$-means

Gambar 4(b), 4(c) dan 4(d) merupakan hasil dari proses k-means, perbedaan dari semua gambar yang diolah adalah dari nilai $k$ yang diujikan. Nilai $k$ akan berpengaruh pada banyaknya 
jumlah centroid pada pengolahan $k$-means, sehingga mempengaruhi jumlah banyaknya tingkat keabuan dari citra hasil uji sesuai dengan nilai $k$ yang dimasukkan. Tingkat keabuan dari citra hasil pengolahan k-means dapat terlihat bahwa intensitas keabuan citra yang dihasilkan lebih merata dari citra awal atau Gambar 4 (a).

Hasil dari k-means dilakukan graysacale yang nantinya digunakan untuk membuat histogram yang digunakan untuk proses penentuan thresholding untuk segmentasi. Segmentasi yang digunakan adalah multilevel Otsu's thresholding, dari hasil segmentasi menghasilkan dua nilai ambang thresholding yang digunakan untuk menentukan besar kandungan mineral yang terdapat pada sayatan tipis batuan beku.

Tabel 1. Nilai Threshold

\begin{tabular}{|l|l|l|l|l|l|l|l|l|}
\hline \multirow{2}{*}{ Objek } & \multicolumn{9}{|c|}{$\begin{array}{l}\text { Multi otsu } \\
\text { +k-means } \\
\text { k=5 }\end{array}$} & $\begin{array}{l}\text { Multi otsu } \\
\text { +k-means } \\
\text { k=6 }\end{array}$ & \multicolumn{2}{l|}{$\begin{array}{l}\text { Multi otsu } \\
\text { +k-means } \\
k=7\end{array}$} \\
\cline { 2 - 10 } & T1 & T2 & T1 & T2 & T1 & T2 & T1 & T2 \\
\hline Batu 1 & 73 & 154 & 66 & 122 & 47 & 132 & 73 & 149 \\
\hline Batu 2 & 94 & 158 & 52 & 138 & 88 & 162 & 85 & 158 \\
\hline Batu 3 & 69 & 136 & 57 & 91 & 48 & 106 & 61 & 117 \\
\hline Batu 4 & 67 & 140 & 55 & 93 & 45 & 107 & 54 & 110 \\
\hline Batu 5 & 84 & 168 & 77 & 175 & 62 & 137 & 71 & 140 \\
\hline Batu 6 & 90 & 185 & 42 & 144 & 76 & 167 & 67 & 144 \\
\hline Batu 7 & 96 & 180 & 65 & 189 & 71 & 157 & 70 & 159 \\
\hline Batu 8 & 77 & 157 & 67 & 115 & 55 & 136 & 69 & 143 \\
\hline Batu 9 & 66 & 146 & 50 & 146 & 42 & 111 & 57 & 123 \\
\hline Batu 10 & 88 & 177 & 39 & 132 & 70 & 159 & 63 & 137 \\
\hline Batu 11 & 71 & 149 & 57 & 151 & 46 & 112 & 56 & 117 \\
\hline Batu 12 & 55 & 136 & 45 & 90 & 35 & 106 & 48 & 116 \\
\hline
\end{tabular}

Tabel 1 merupakan hasil dari perhitungan Algoritma Multilevel Otsu's Threshloding dengan dua titik ambang yang akan digunakan sebagai batas threshold dan pada daerah hasil segmentasi merupakan nilai kelimpahan dari mineral. Pada ambang kedua (T2) merupakan nilai ambang yang digunakan untuk mencari nilai kelimpahan dari mineral plagioclase karena mineral plagioclase memiliki karakteristik warna putih dan nada juga yang berwarna keabuabuan dan kecoklat-coklatan karena terkena pelapukan pada mineral plagioclase tersebut.

Tabel 2. Hasil Perhitungan Mineral

\begin{tabular}{|l|c|c|c|c|c|c|c|c|c|c|}
\hline \multirow{2}{*}{ Objek } & \multicolumn{2}{|c|}{ Multi otsu } & \multicolumn{2}{c|}{$\begin{array}{c}\text { Multi otsu + } \\
\text { k-means } \boldsymbol{k = 5}\end{array}$} & $\begin{array}{c}\text { Multi otsu + k- } \\
\text { means } \boldsymbol{k = 6}\end{array}$ & $\begin{array}{c}\text { Multi otsu + k- } \\
\text { means } \boldsymbol{k = 7}\end{array}$ & \multicolumn{2}{c|}{ Ahli } \\
\cline { 2 - 13 } & M1 & M2 & M1 & M2 & M1 & M2 & M1 & M2 & M1 & M2 \\
\hline Batu 1 & 58.14 & 23.9 & 63.6 & 36.39 & 55.75 & 33.51 & 63.29 & 28.01 & 10 & 45 \\
\hline Batu 2 & 40.06 & 36.12 & 31.76 & 52.39 & 45.18 & 40.86 & 43.74 & 42.95 & 5 & 70 \\
\hline Batu 3 & 52.02 & 19.85 & 55.78 & 44.21 & 46.92 & 34.93 & 55.39 & 29.62 & 3 & 50 \\
\hline Batu 4 & 50.46 & 20.06 & 30.71 & 44.35 & 24.32 & 35.57 & 34.75 & 33.76 & 1 & 45 \\
\hline Batu 5 & 49.82 & 23.36 & 35.47 & 26.26 & 27.53 & 35.52 & 36.25 & 34.07 & 5 & 60 \\
\hline Batu 6 & 49.69 & 31.88 & 39 & 42.71 & 52.2 & 38.4 & 47.51 & 41.62 & 5 & 70 \\
\hline Batu 7 & 53.26 & 23.17 & 35.47 & 24.9 & 35.47 & 24.9 & 27.81 & 33.42 & 10 & 40 \\
\hline Batu 8 & 52.69 & 22.3 & 36.78 & 40.68 & 51.35 & 32.91 & 41.95 & 30.38 & 10 & 70 \\
\hline Batu 9 & 58.77 & 15.59 & 36.46 & 20.44 & 29.69 & 28.24 & 46.52 & 24.07 & 15 & 25 \\
\hline Batu 10 & 52.44 & 24.08 & 33.81 & 32.66 & 33.81 & 32.66 & 49.84 & 37.4 & 5 & 32 \\
\hline
\end{tabular}




\begin{tabular}{|l|c|c|c|c|c|c|c|c|c|c|}
\hline \multirow{2}{*}{ Objek } & \multicolumn{2}{|c|}{ Multi otsu } & \multicolumn{2}{|c|}{$\begin{array}{c}\text { Multi otsu + } \\
\text { k-means } \boldsymbol{k}=\mathbf{5}\end{array}$} & \multicolumn{2}{c|}{$\begin{array}{c}\text { Multi otsu + k- } \\
\text { means } \boldsymbol{k}=\mathbf{6}\end{array}$} & \multicolumn{2}{c|}{$\begin{array}{c}\text { Multi otsu + k- } \\
\text { means } \boldsymbol{k}=\mathbf{7}\end{array}$} & \multicolumn{2}{c|}{ Ahli } \\
\cline { 2 - 12 } & M1 & M2 & M1 & M2 & M1 & M2 & M1 & M2 & M1 & M2 \\
\hline Batu 11 & 55.63 & 17.02 & 31.98 & 21.86 & 23.08 & 31.86 & 37.01 & 29.2 & 10 & 30 \\
\hline Batu 12 & 69.39 & 12.58 & 53.39 & 25.13 & 44.97 & 20.14 & 59.72 & 17.92 & 10 & 35 \\
\hline
\end{tabular}

Tabel 2 merupakan tabel hasil perhitungan yang dilakukan pada 12 citra sayatan tipis batuan beku kolom ahli merupakan hasil pengamatan yang dilakuakn ahli secara manual yang nantinya akan di bandingkan dengan hasil yang diperoleh dari perhitungan prototype. Dari hasil yang didapatkan kemudaian diberi nama sesuai dengan kandungan mineral plagioclase yang dikandung.

Nilai M2 merupakan nilai dari kelimpahan mineral plagioclase yang dikandung pada sayatan tipis batuan beku, seperti pada sayatan tipis batu 1 memiliki kandungan mineral plagioclase sebanyak $23.9 \%$ pada perhitungan menggunakan mulitilevel otsu's thresholding, sedangkan pada perhitungan menggunakan mulitilevel otsu's thresholding dengan pengolahan $\mathrm{k}$-means dengan nilai $\mathrm{k}=5$ menghasilkan $36.39 \%$ kandungan mineral plagioclase, dan jika menggunkan pengolahan mulitilevel otsu's thresholding dengan pengolahan $k$-means dengan nilai $\mathrm{k}=6$ menghasilkan $33.51 \%$ mineral plagioclase, dan pada pengolahan mulitilevel otsu's thresholding dengan pengolahan $k$-means dengan nilai $\mathrm{k}=7$ menghasilkan $28.01 \%$ mineral plagioclase.

Tabel 3. Hasil Penamaan Batuan Gabbro

\begin{tabular}{|c|c|c|c|c|c|c|c|c|c|c|c|c|c|c|c|}
\hline \multirow{2}{*}{ Objek } & \multicolumn{3}{|c|}{ Multi otsu } & \multicolumn{3}{|c|}{$\begin{array}{l}\text { Multi otsu + } \\
\text { k-means } k=5\end{array}$} & \multicolumn{3}{|c|}{$\begin{array}{l}\text { Multi otsu + } \\
\text { k-means } k=6\end{array}$} & \multicolumn{3}{|c|}{$\begin{array}{l}\text { Multi otsu + } \\
\text { k-means } k=7\end{array}$} & \multicolumn{3}{|c|}{ Ahli } \\
\hline & K1 & K2 & K3 & K1 & K2 & K3 & K1 & K2 & K3 & K1 & K2 & K3 & K1 & K2 & K3 \\
\hline Batu 1 & $\sqrt{ }$ & & & & $\sqrt{ }$ & & $\sqrt{ }$ & & & $\sqrt{ }$ & & & & $\sqrt{ }$ & \\
\hline Batu 2 & & $\sqrt{ }$ & & & $\sqrt{ }$ & & & $\sqrt{ }$ & & & $\sqrt{ }$ & & & & $\sqrt{ }$ \\
\hline Batu 3 & $\sqrt{ }$ & & & & $\sqrt{ }$ & & $\sqrt{ }$ & & & $\sqrt{ }$ & & & & $\sqrt{ }$ & \\
\hline Batu 4 & $\sqrt{ }$ & & & & $\sqrt{ }$ & & & $\sqrt{ }$ & & $\sqrt{ }$ & & & & $\sqrt{ }$ & \\
\hline Batu 5 & $\sqrt{ }$ & & & $\sqrt{ }$ & & & & $\sqrt{ }$ & & $\sqrt{ }$ & & & & $\sqrt{ }$ & \\
\hline Batu 6 & $\sqrt{ }$ & & & & $\sqrt{ }$ & & & $\sqrt{ }$ & & & $\sqrt{ }$ & & & & $\sqrt{ }$ \\
\hline Batu 7 & $\sqrt{ }$ & & & $\sqrt{ }$ & & & $\sqrt{ }$ & & & $\sqrt{ }$ & & & & $\sqrt{ }$ & \\
\hline Batu 8 & $\sqrt{ }$ & & & & $\sqrt{ }$ & & $\sqrt{ }$ & & & $\sqrt{ }$ & & & & & $\sqrt{ }$ \\
\hline Batu 9 & $\sqrt{ }$ & & & $\sqrt{ }$ & & & $\sqrt{ }$ & & & $\sqrt{ }$ & & & $\sqrt{ }$ & & \\
\hline Batu 10 & $\sqrt{ }$ & & & $\sqrt{ }$ & & & $\sqrt{ }$ & & & & $\sqrt{ }$ & & $\sqrt{ }$ & & \\
\hline Batu 11 & $\sqrt{1}$ & & & $\sqrt{ }$ & & & $\sqrt{ }$ & & & $\sqrt{ }$ & & & $\sqrt{ }$ & & \\
\hline Batu 12 & $\sqrt{ }$ & & & $\sqrt{ }$ & & & $\sqrt{ }$ & & & $\sqrt{ }$ & & & $\sqrt{ }$ & & \\
\hline
\end{tabular}

Keterangan:

$\mathrm{K} 1$ = untuk mengklasifikasikan jenis batuan masuk kedalam golongan Leuco-Gabbro.

$\mathrm{K} 1$ = untuk mengklasifikasikan jenis batuan masuk kedalam golongan Gabbro.

$\mathrm{K} 1$ = untuk mengklasifikasikan jenis batuan masuk kedalam golongan Mela-Gabbro.

Tabel hasil penamaan batuan gabbro hanya diambil dari Perhitungan Prototype dengan k-means $\mathrm{k}=5$ dan Perhitungan Prototype dengan $k$-means $\mathrm{k}=6$ karena pada komposisi termesut memiliki nilai rata-rata RAE yang kecil dibandingkan dengan komposisi yang lainnya. Penamaan nama batuan berdasarkan standar klasifikasi batuan beku gabbro IUGS dengan ketentuan. Jika kandungan mineralnya kurang dari 35\%, nama batuan dapat di awali dengan leuco- yang berarti terang. Jika kandungan mineralnya lebih dari $65 \%$, maka penamaan batuan dapat di awali dengan mela- yang berarti gelap, dan jika diantara 65\%-35\% maka batuan tersebut di berinama Gabbro. 
Jatisi, Vol. 4 No. 1 September 2017

Tabel 4. Perhitungan Confusion Matrix dengan Multilevel Otsu's Thresholding

\begin{tabular}{|c|c|c|c|c|}
\hline \multirow{3}{*}{$\begin{array}{c}\text { Data Aktual } \\
\text { dari Ahli }\end{array}$} & \multicolumn{4}{|c|}{ Data Prediksi dari Prototype } \\
\cline { 2 - 5 } & Mela- gabbro & Mela- gabbro & gabbro & Leuco- gabbro \\
\cline { 2 - 5 } & Gabbro & 5 & 0 & 0 \\
\cline { 2 - 5 } & Leuco-gabbro & 2 & 0 & 0 \\
\hline
\end{tabular}

Tabel 5. Perhitungan Confusion Matrix dengan Multilevel Otsu's Thresholding dan $k$-means dengan nilai $\mathrm{k}=5$

\begin{tabular}{|c|c|c|c|c|}
\hline & \multicolumn{4}{|c|}{ Data Prediksi dari Prototype } \\
\hline \multirow{3}{*}{$\begin{array}{c}\text { Data Aktual } \\
\text { dari Ahli }\end{array}$} & Mela- gabbro & gabbro & Leuco- gabbro \\
\cline { 2 - 5 } & Mela- gabbro & 0 & 0 & 0 \\
\cline { 2 - 5 } & Gabbro & 2 & 7 & 0 \\
\cline { 2 - 5 } & Leuco- gabbro & 0 & 3 & 0 \\
\hline
\end{tabular}

Tabel 6. Perhitungan Confusion Matrix dengan Multilevel Otsu's Thresholding dan $k$-means dengan nilai $\mathrm{k}=6$

\begin{tabular}{|c|c|c|c|c|}
\hline & \multicolumn{4}{|c|}{ Data Prediksi dari Prototype } \\
\hline \multirow{3}{*}{$\begin{array}{c}\text { Data Aktual } \\
\text { dari Ahli }\end{array}$} & Mela- gabbro & gabbro & Leuco- gabbro \\
\cline { 2 - 5 } & Mela- gabbro & 4 & 0 & 0 \\
\cline { 2 - 5 } & Gabbro & 3 & 2 & 0 \\
\cline { 2 - 5 } & Leuco- gabbro & 1 & 2 & 0 \\
\hline
\end{tabular}

Tabel 7. Perhitungan Confusion Matrix dengan Multilevel Otsu's Thresholding dan $k$-means dengan nilai $\mathrm{k}=7$

\begin{tabular}{|l|c|c|c|c|}
\hline & \multicolumn{4}{|c|}{ Data Prediksi dari Prototype } \\
\hline \multirow{3}{*}{$\begin{array}{l}\text { Data Aktual } \\
\text { dari Ahli }\end{array}$} & Mela- gabbro & gabbro & Leuco- gabbro \\
\cline { 2 - 5 } & Mela- gabbro & 3 & 1 & 0 \\
\cline { 2 - 5 } & Gabbro & 5 & 0 & 0 \\
\cline { 2 - 5 } & Leuco- gabbro & 1 & 2 & 0 \\
\hline
\end{tabular}

\section{KESIMPULAN}

Hasil perhitungan dan analisis yang telah dilakukan Algoritma Multilevel Otsu's Thresholding menghasilkan akurasi yang cukup baik pada jenis batuan tertentu seperti pada penggunaan Algoritma Multilevel Otsu's Thresholding tanpa k-means menghasilkan tingkat akurasi hingga 91,7\% pada jenis batuan Mela-gabbro, sedangkan pada penggunaan Algoritma Multilevel Otsu's Thresholding dan $k$-means dengan nilai k= 7 menghasilkan akurasi hingga $75 \%$ pada jenis batuan Mela-gabbro. Dan pada jenis batuan jenis gabbro menghasilkan akurasi tertinggi pada Algoritma Multilevel Otsu's Thresholding dan k-means dengan nilai k= 5 menghasilakan akurasi hingga 58\%, dan pada penamaan jenis batuan Leuco-gabbro memiliki tingkat akurasi tertinggi 20\% dengan menggunakan Algoritma Multilevel Otsu's Thresholding dan $k$-means dengan nilai $\mathrm{k}=7$. Penggunaan $k$-means cukup berpengaruh banyak dalam pengolahan citra sayatan tipis pada jenis batuan gabbro dengan hasil terbaik dengan mengenali semua jenis batuan gabbro dengan tingkat akurasi $75 \%$ untuk batuan Mela-gabbro, 25\% untuk batuan gabbro dan 20\% untuk batuan Leuco-gabbro dengan nilai $\mathrm{k}=7$, sedangkan pada Algoritma Multilevel Otsu's Thresholding tanpa menggunakan k-means tidak dapat mengenali semua jenis batuan gabbro kerena pada jenis batuan Leuco-gabbro memiliki akurasi $0 \%$. 


\section{SARAN}

Perlu dilakukan beberapa perbaikan pada penelitian yang telah dilakuan diantaranya melakukan perngujian terhadap batuan yang lain, melakukan optimalisasi pada algoritma Multilevel Otsu's Thresholding dan menambah jenis klasifikasi pada jenis batuan beku.

\section{DAFTAR PUSTAKA}

[1] Khoirul Umam dkk, 2014, Segmentasi pada Citra Panoramik Gigi dengan Metode Two-Stage SOM dan T-Cluster, ULTIMA Computing, pp. Vol. VI, No. 1.

[2] Deng-Yuan Huang, 2011, Automatic Multilevel Threshold Based on Two-Stage Otsu's Method with Cluster Determination by Valley Estimation, ICIC Internatioanal, Volume 7, pp. hal.5631-5644.

[3] Raju, P.Daniel Ratna, 2012, Image Segmentation by using Histogram Thresholding, IJCSET, Vol 2, Issue 1, hal 776-779.

[4] Acharya, Tinku, 2005, Image Processing: Principles and Applications / Tinku Acharya, Ajoy K. Ray, John Wiley \& Sons, Inc., Hoboken, New Jersey, Canada.

[5] Kumar, Xindong $\mathrm{Wu}$ and Vipin, 2009, The Top Ten Algoritms in Data Mining, CRC Press, London.

[6] Shofwatul, 'Uyun, Hartati Sri, Harjoko Agus, and Choridah Lina, 2015, A Comparative Study of Thresholding Algorithms on Breast Area and Fibroglandular Tissue, International Journal of Advanced Computer Science and Applications, hal 120-124. 